\title{
Sociomaterialidade, Poder e Conexões em Redes de Ação no Organizar do Artesanato
}

\author{
Sociomateriality, Power and Connections in the Action Nets in the Handcraft \\ Organization
}

\author{
Christianne Lobato Ramalho da Silva ${ }^{1}$ \\ (D) https://orcid.org/0000-0002-1265-5157 \\ Alfredo Rodrigues Leite da Silva ${ }^{2}$ \\ (iD) https://orcid.org/0000-0002-5943-1185
}

Universidade Federal de Alagoas, Pró-Reitoria de Gestão de Pessoas, Maceió, AL, Brasil ${ }^{1}$ Universidade Federal do Espírito Santo, Departamento de Administração, Vitória, ES, Brasil ${ }^{2}$

Artigo recebido em 15.02.2018. Última versão recebida em 08.02.2019. Aprovado em 11.02.2019. Editor-chefe: Prof. Wesley Mendes-Da-Silva.

\# de revisores convidados até a decisão

\begin{tabular}{|c|c|c|c|c|c|c|c|c|}
\hline & 1 & 2 & 3 & 4 & 5 & 6 & 7 & 8 \\
\hline $1^{\mathrm{a}}$ rodada & $\otimes$ & $\otimes$ & $\otimes$ & 9 & $\otimes$ & $\stackrel{9}{3}$ & & \\
\hline $2^{a}$ rodada & $\stackrel{8}{2}$ & & & & & & & \\
\hline
\end{tabular}




\title{
Resumo
}

Este artigo objetiva compreender o papel da sociomaterialidade e das relações de poder nas conexões em redes de ação no organizing do artesanato sob a ótica certeauniana. Ele trata da maneira que o poder é articulado em estudos sobre o artesanato, para propor a análise das relações de poder na sociomaterialidade do organizar da prática artesanal. Para isso articula a abordagem das redes de ação com contribuições certeaunianas sobre as relações de forças no cotidiano e aplica a proposta em uma investigação sobre as filezeiras, artesãs de Maceió/AL. Os dados foram coletados por meio de entrevistas, observação participante e shadowing e tratados com o uso da Análise do Conteúdo, na modalidade temática. Nos resultados a sociomaterialidade do artesanato envolveu transgressões a lugares de poder estabelecidos ou convergências com esses lugares. Como conclusão, enquanto objeto não humano $\mathrm{o}$ artesanato se revelou como um objeto de fronteira, ligando diferentes domínios. Enquanto prática o artesanato se viabilizou por redes de ação nesses domínios, com ações conectadas por relações de poder. Os conflitos e as desagregações estão presentes nas relações de poder, assim como as conexões. Essa maleabilidade das relações de poder permite compreender a produção comum de artesãos, no cotidiano de conflitos, desagregações e conexões.

Palavras-chave: redes de ação; artesanato; organizing; sociomaterialidade; relações de poder.

\begin{abstract}
The aim of the current article is to investigate the role played by sociomateriality and power relations in action networks focused on organizing craftsmanship processes, based on the Certeaunian perspective. It addresses the way power is articulated in studies about craftsmanship and analyzes power relations in the sociomateriality of craftsmanship-practice organization. Moreover, it articulates the approach of action networks and Certeaunian contributions to power relations in the daily life of individuals in order to investigate the case of filezeiras (artisans from Maceió County/AL). Data were collected through interviews, participant observation and shadowing techniques, as well as subjected to Content Analysis, based on the thematic modality. Craftsmanship sociomateriality involved transgressions to places of established power or convergences towards these places. Finally, as non-human object, craftsmanship is a frontier object linking different domains, whereas as practice, it is enabled by action networks in these domains, where actions are connected through power relations. Conflicts and disagreements are seen in power relations, as well as connections. This malleability of power relations allows better understanding the common production of craftsmen in daily conflicts, disaggregations and connections.
\end{abstract}

Keywords: action nets; handcraft; organizing; sociomateriality; power relations.

JEL Code: Z11, D85, L14. 


\section{Introdução}

Este artigo se insere na discussão sobre redes de ação (action nets) ao tratar da conexão entre as ações (Lindberg \& Czarniawska, 2006). De maneira específica, propomos articular as relações de poder, na ótica certeauniana, para revelar parte da dinâmica dessas conexões no organizing do artesanato do bordado filé de Maceió/AL, com o objetivo de compreender o papel da sociomaterialidade e das relações de poder nas conexões em redes de ação no organizar do artesanato.

A abordagem das redes de ação se volta para conexões em um tempo e espaço que podem ultrapassar um campo organizacional e coloca a ação em primeiro lugar, uma rede de atores, se existir, vem depois, produzida pelas ações (Lindberg \& Czarniawska, 2006).

Neste estudo essa concepção foi articulada com a abordagem certeauniana para tratar dos efeitos do poder como parte das conexões entre ações em redes. Um aspecto, comumente, não abordado nos estudos sobre redes de ação, uma lacuna preenchida por este artigo.

Ao tratar dessas conexões o foco no artesanato se justifica por ele oferecer potencial de inclusão social ao viabilizar a realização de um ofício, o de artesão (Barbosa \& D'Ávila, 2014). Ao mesmo tempo, o organizar do artesanato é vinculado a múltiplas ações em redes em domínios distintos, com relações envolvendo cultura, estilo de vida (Sennett, 2009), aspectos econômicos, de gênero (Figueiredo, Melo, Matos, \& Machado, 2015) e institucionais.

Na abordagem adotada o termo organizar substitui o termo organização, para enfatizar a dinâmica organizacional (Weick, 1969), envolvendo formas materiais e atores em interações cotidianas (Orlikowski, 2007), na qual o artesanato se constitui. A discussão se insere na virada material nos estudos organizacionais, voltada para a dinâmica sociomaterial (Orlikowski, 2007; Pozzebon et al., 2017).

O artesanato é tratado aqui com base na abordagem de Certeau (1998) sobre o poder e as práticas no cotidiano, na qual o foco nas relações, e não nos indivíduos nem nos objetos, é o caminho para compreender as práticas, indissociáveis do cotidiano de indivíduos e objetos. Assim como defende o autor, assumimos que o "exame dessas práticas não implica um regresso aos indivíduos" (Certeau, 1998, p. 37).

As contribuições de Certeau (1986; 1998; 2012) nos estudos organizacionais não são algo novo, mas apresentam um amplo potencial pouco explorado (Faria \& Silva, 2017a). Neste artigo as articulamos com a concepção de redes de ação (Czarniawska, 2004, 2008) para compreender um aspecto pouco explorado nos estudos sobre redes de ação no organizing do artesanato: o papel das relações de poder nas conexões entre as ações em uma rede.

Como explicam Corvellec e Czarniawska (2015), dentro de uma ordem institucional a percepção da dependência entre ações coletivas existentes as levam a conexões em redes de ação. Além disso, novas ações coletivas podem se conectar em redes de ação, por isso ser visto como um meio para ir além do que está institucionalizado. Entretanto, ao tratar desses aspectos a abordagem das redes de ação não se volta para as relações de poder como efeitos: (a) no embate entre diferentes ordens institucionalizadas pelas ações conectadas entre si; (b) e na resistência a partir de ações além das ordens institucionalizadas. Este artigo se volta para o preenchimento desta lacuna ao tratar o poder como parte das conexões nas redes de ação (Czarniawska, 2004, 2008), com foco nas práticas e relações cotidianas (Certeau, 1998), a partir do seguinte problema de pesquisa: como a sociomaterialidade e as relações de poder fazem parte das conexões nas redes de ação no organizar do artesanato?

Ao longo do artigo discutimos as potencialidades das proposições teóricas apresentadas e as inconsistências epistemológicas entre as abordagens articuladas, que foram conciliadas. Confrontamos as proposições com dados empíricos de uma investigação tendo como unidade de análise as ações das filezeiras, artesãs do bairro do Pontal da Barra na cidade de Maceió/AL. Em torno do artesanato delas 
surgem diferentes práticas, disparidades sociais e econômicas e manifestações culturais, fazendo parte do organizing do artesanato.

A escolha do lócus de investigação se justificou por diversos motivos. O artesanato bordado filé foi reconhecido como patrimônio cultural imaterial do estado de Alagoas (Amorim, 2016) e foram definidos aspectos materiais específicos do bordado. Isso oferecia a oportunidade de investigar atores sociais, produtores criativos de um artesanato de alcance socioeconômico estadual, lidando com essa materialidade. O Pontal da Barra é referência compartilhada por moradores da cidade e do estado para a compra de artesanato e um ponto turístico relevante à visitação. Uma referência marcada pela sociomaterialidade que envolve o local, presente no estilo de vida típico, na aparência e nas redes de ação das filezeiras em relações com a mídia, o Estado e outros atores, levando o organizar de sua produção artesanal a perdurar e se desenvolver até a atualidade. Esses fatores indicam a relevância do lócus e justificam sua escolha em relação ao objetivo proposto.

Após a escolha do lócus a investigação se deu por meio de entrevistas, observação participante e shadowing. Os dados foram analisados por meio da análise de conteúdo na modalidade temática. Para apresentar os resultados alcançados com esses dados este artigo foi organizado da seguinte maneira: discutimos o lugar de poder do artesanato em termos de suas relações com as redes de ação, a abordagem certeauniana e a sociomaterialidade para, depois, com foco na sociomaterialidade no organizar, nos aprofundarmos nas implicações epistemológicas das articulações propostas; em seguida, apresentamos o percurso metodológico, a análise das evidências empíricas e as considerações finais.

\section{O Lugar de Poder do Artesanato}

$\mathrm{O}$ artesanato é uma das atividades mais antigas da humanidade e ainda é realizado em todas as partes do mundo, articulando elementos culturais, sociais e econômicos (Leite \& Sehnem, 2018). A sua origem se refere a necessidades funcionais e cerimoniais (Popelka \& Littrell, 1991), em torno das quais reflete o clima, a geografia, o modo de vida, entre outros aspectos de uma comunidade (Vargas \& Cancelier, 2018). Atualmente, esses reflexos se inserem na cultura que sustenta o artesanato, comumente, também submetida a influências econômicas do mercado (Calíope, Conceição, Santos, \& Pessoa, 2016).

Para Ramos (2013) a sobrevivência baseada na venda do artesanato, como fonte de renda principal, gera a submissão às exigências do mercado, em detrimento da produção espontânea do saber artesanal. Essa submissão cria uma situação propícia para o surgimento de estudos organizacionais transpondo ao artesanato lógicas e tecnologias empresariais.

Dentro dessa ótica Leite e Sehnem (2018) propõem um modelo de gestão sustentável e competitivo para o artesanato, que apresenta como parte de suas contribuições "a inserção de fatores relacionados, tais como: o empreendedorismo, a profissionalização, a consolidação de cadeias produtivas, redes de relacionamentos e a congregação de instrumentos de gestão" (p. 283). Em uma abordagem semelhante C. F. Oliveira e Veiga (2008) tratam dos obstáculos para que o artesanato nordestino seja negociado nos mercados internacionais. Também com foco no mercado, Bento e Silva (2016) defendem o emprego da certificação como ferramenta de marketing para ampliar a competitividade do artesanato, por meio da definição e comprovação de padrão de qualidade e origem.

Essas propostas se inserem na corrente predominante nos estudos organizacionais, com foco em intervenções gerencialistas (Faria \& Silva, 2017b; Marquesan \& Figueiredo, 2014), para obter determinados resultados organizacionais. Nessa abordagem cabe destacar a ausência da discussão sobre as relações de poder em torno do artesanato, foco deste artigo.

Tal silenciamento não ocorre nos estudos que criticam a abordagem gerencialista no artesanato. Eles afirmam que a abordagem leva os artesãos a uma submissão à lógica empresarial e econômica, perdendo sua autonomia ao adotar técnicas e padrões funcionais e estéticos em função de relações de 
poder estabelecidas pela dependência com o mercado, que não necessariamente são os definidos com base na tradição (Marquesan \& Figueiredo, 2014).

J. S. Oliveira, Cavedon e Figueiredo (2012) criticam esse gerencialismo evidenciado na tentativa do poder público, dentre outros agentes, de enquadrar os artesãos na comercialização capitalista como empreendedores ou microempresários. Mas para as autoras esse enquadramento econômico se transforma em apenas uma, dentre muitas interações na ligação do artesão com sua produção, que incluem a capacidade de ele agir e intervir no artesanato, suas interações sociais e com o público consumidor, diluindo a lógica de mercado.

$\mathrm{Na}$ abordagem que foca na crítica ao gerencialismo o poder é tratado como uma causa que explica pelo menos parte do que acontece com o artesanato, em função das relações econômicas (Marquesan \& Figueiredo, 2014). Em outra ótica, os estudos enquadrados em abordagens diversas não assumem a postura gerencialista, nem priorizam a crítica a ela, eles buscam discutir manifestações ou aspectos específicos do artesanato (Vargas \& Cancelier, 2018) e ou tratar do seu potencial como lente teórica (Figueiredo, 2014).

Dentre esses estudos estão os que, a despeito de não tratarem diretamente do poder, assumem uma postura na qual os artesãos são colocados como protagonistas das mudanças, usando o mercado, não sendo simplesmente submissos a ele. Para Vargas e Cancelier (2018) ficou evidente a iniciativa dos artesãos para se inserirem no mercado consumidor sem romper com a tradição. $\mathrm{O}$ crescimento dessa oferta por parte da iniciativa deles ocorreu ao identificarem demandas por sua tradição e passaram a comercializar seus produtos para além do seu convívio social, em feiras e lojas de produtos típicos em centros urbanos, manifestando a dinâmica própria do artesanato, nas alterações que ocorrem baseadas na tradição.

Em outro estudo Leistner (2018) apresenta as relações de poder como articulações simbólicas nas quais, inicialmente, os artesãos alinhados com a lógica mercadológica do SEBRAE se destacam, mas quando a instituição tenta excluir artesãos tradicionais, desalinhados com suas diretrizes, todos rompem com ela. A partir desse episódio o autor evidenciou a possibilidade de se conciliar, por meio da organização dos próprios artesãos, a atuação no mercado com a manutenção de práticas e valores tradicionais, em um hibridismo nos elementos simbólicos articuladores do grupo de artesãos entre o periférico, da tradição, e o urbano, do mercado.

De maneira semelhante, Sapiezinskas (2012) trata dos embates simbólicos entre três instâncias: o SEBRAE, enquanto uma instituição organizadora do artesanato; um grupo de artesãs de Brasília; e os designers, encarregados de fazer a mediação entre os dois anteriores. O papel gerencialista do SEBRAE e dos designers está presente em evidências empíricas reproduzidas no texto, mas a autora opta por destacar o caráter múltiplo e simbólico das relações em torno das artesãs. Para ela o poder é exercido pelas artesãs ao colocarem em jogo uma visão própria da sua atividade, ao produzirem o artesanato.

Um aspecto comum a esses estudos que discutem o poder do artesão é a sua relação com a produção do conhecimento e a aprendizagem que ocorre na prática, na medida que o aprendiz vai se tornando um artesão, obtendo sua maestria (Figueiredo \& Ipiranga, 2015). Inclusive pode ser um prérequisito para aceitação em um grupo em uma comunidade de artesãos (Ferreira, Helal, \& Paiva, 2016).

Entretanto, neste artigo, não entendemos o poder como uma causa, que é possível, por exemplo, quando o artesão aprendeu seu ofício e passou a possuir esse poder, ou pelo potencial simbólico que ele detém. Aqui assumimos que o poder é um efeito (Cardoso \& Hirata, 2017), produzido em redes, e ao assumir esse entendimento devemos explicar esse efeito nas redes de ação (Czarniawska, 2004).

A Teoria Ator-Rede (TAR) influenciou a abordagem das redes de ação e articula esse efeito numa perspectiva simétrica, entre atores humanos e não-humanos, para revelar o poder como efeitos que levam às conexões entre atores sociais e à manutenção delas, nas articulações entre práticas e arranjos materiais. O poder é exercido pelos atores e se altera quando conexões na rede se alteram (Alcadipani \& Tureta, 2009; Callon, 1986; Latour, 1996). 
A ideia de poder como efeito é anterior à TAR, ela já estava presente nas propostas de Foucault (1977) e existem afinidades entre elas, mas o autor não trata da simetria e nem da tradução das distinções entre atores em função de um objetivo partilhado, entre outras diferenças (Cardoso \& Hirata, 2017; Law, 1992), que fogem do escopo deste artigo.

Foucault (1977) influenciou também a proposta de Certeau (1998) sobre poder, na qual os efeitos dos procedimentos disciplinares produzem relações de forças no cotidiano, circunscritas a lugares de poder privilegiados. Mas, Certeau (1998) afirma se opor à abordagem foucaultiana ao defender que essa disciplina é transgredida pela rede de uma antidisciplina, baseada no uso astucioso e oportunista dos próprios procedimentos disciplinares. Esse uso é a resistência nas táticas de transgressão da disciplina.

Em comum a todas essas abordagens está a concepção do poder como efeito, e foi adotada neste artigo ao nos aproximarmos das contribuições certeaunianas. Por exemplo, na produção do artesanato o uso pelo artesão de uma linha de algodão, tecidos e um processo produtivo, considerados tradicionais, pode ter como efeito a obtenção de um certificado de origem que identifica um artesanato regional. Isso é uma manifestação do poder, e esse certificado passa a fazer parte de novas ações e novos efeitos, e assim por diante. Não se trata do poder existir ou não, mas de alterar suas distribuições nos efeitos quando as ações surgem, se alteram ou se desconectam de uma rede de ação. Propomos o estudo dessa dinâmica de efeitos que envolve elementos sociais e materiais, como os exemplificados acima.

Ao propor um caminho para esse estudo adotamos um entendimento de sociomaterilidade como sendo o reconhecimento do "emaranhamento constitutivo do social e do material na vida organizacional cotidiana" e que concebe as práticas sociais como também materiais (Orlikowski, 2007, p. 1438). Nessa ótica o poder é visível e investigável a partir das relações entre a dimensão dos elementos sociais e materiais e dos efeitos (poder) sobre eles.

Um exemplo dessa sociomaterialidade é um artesão que usa uma linha sintética no lugar da tradicional de algodão e, ao ser descoberto, é expulso da associação de artesãos. Aqui as relações sociomateriais, envolvendo a linha sintética e a tradicional, o artesão e a associação, revelam relações de poder que conectam esses elementos nas redes de ação do artesanato. Sem a análise dessa sociomaterilidade essa dinâmica do poder e da resistência ficaria oculta no cotidiano invisível das conexões nas redes de ação do artesanato.

Nesse cotidiano as relações envolvendo os efeitos das ações estabelecem lugares de poder privilegiados, como o do mercado, que também são passíveis de resistência por meio de ações táticas (Certeau, 1998). Tais ações incluem aspectos locais e identitários que corroboram para a manutenção da atividade artesanal. Como explica Sapiezinskas (2012), a identidade do artesão não se restringe a obter renda a partir do artesanato ou a dominar uma técnica artesanal, ela é uma construção social com um significado próprio, com base em uma referência cultural. Nessa construção defendemos que as relações entre ações, nas práticas cotidianas, estabelecem o lugar de poder do artesanato.

A ênfase nas ações na prática cotidiana como um caminho para construir e revelar lugares de poder e a resistência a esses lugares é um aspecto relevante e distintivo em Certeau (1998), pois ele tem uma preocupação específica em revelar os mecanismos de resistência. Neste artigo esses mecanismos são considerados relevantes para investigar o organizar do artesanato na ótica de uma heterogeneidade cultural produzida no cotidiano. Para lidar com esse desafio propomos a articulação da concepção de redes de ação com contribuições certeaunianas sobre as relações de poder, com foco na sociomaterialidade no organizar.

\section{O Poder na Sociomaterialidade no Organizar: Certeau e Conexões em Redes de Ação}

O estudo do organizar tem como precursora a proposta de Weick (1969) em substituir o substantivo organização, que enfatiza aspectos estabilizados e definidos, pelo termo organizing, um verbo traduzido aqui como organizar ou processo de organizar, para enfatizar o caráter dinâmico e 
contínuo do processo organizacional. Ele é marcado pela ambiguidade, pois é considerado como conjuntos de relações em ciclos interligados e dinâmicos (Czarniawska, 2010). Por isso a análise do organizar permite enfatizar a heterogeneidade nas micropráticas e investigar processos que a constituem (Duarte \& Alcadipani, 2016).

Orlikowski (2007, p. 1440, tradução nossa) sugere abordar o organizar em uma perspectiva na qual o social e o material se encontram intrincados na vida cotidiana, resultando no "emaranhado constitutivo do social e do material". Nesse emaranhamento constitutivo as práticas cotidianas são sempre e em toda parte sociomateriais. Por isso, a dinâmica da vida cotidiana pode ser revelada pela sociomaterialidade (Lemos, 2017).

O papel do social é comumente abordado nos estudos organizacionais, mas com a virada material (Pozzebon et al., 2017) surgiram estudos que colocam o papel do material no mesmo patamar, como participantes do processo contínuo de organizar (Lindberg \& Walter, 2013). Por exemplo, Orlikowski (2007) estudou a interdependência entre a funcionalidade do motor de busca do Google e a criação cotidiana de páginas por meio da atuação humana. Em outro estudo, Scarbrough, Panourgias e Nandhakumar (2015) identificaram que a organização de múltiplas tarefas colaborativas pode ser auxiliada pelas relações entre os objetos.

Nos dois exemplos a sociomaterialidade é abordada como imersa nas redes de ação analisadas. Czarniawska (2004) descreve as redes de ação como uma abordagem para compreender o organizar, originada em articulações entre o velho e o novo institucionalismo e a teoria ator-rede (Feldman, 2017). A abordagem é baseada na ideia da existência de um conjunto de instituições, em cada tempo e lugar, de modo que as percepções sobre essas instituições fazem com que as ações se conectem, formando redes, pois identificam isso como necessário em virtude do que está institucionalizado ou para alcançar objetivos que rompem com a ordem institucionalizada (Corvellec \& Czarniawska, 2015). Nessas redes de ação e em função das ações, as interações entre os atores sociais (humanos e não humanos) ocorrem no tempo e no espaço, produzindo os atores sociais que praticam as ações e formam novas interações, que também produzem o tempo e o espaço.

A partir dessa abordagem defendemos que a análise das redes de ação contribui para a investigação de conexões entre ações coletivas no organizar do artesanato. Cabe destacar que tal abordagem exige o afastamento da ideia de prática apenas relacionada a atividades repetidas rotinas, hábitos. As práticas são consideradas ações coletivas, de humanos e não humanos, em uma relação renovada continuamente (Lindberg \& Walter, 2013). No sentido aqui adotado "as práticas são, de fato, necessariamente situadas (sua realização sempre ocorre dentro de situações específicas) e trans-situadas - as práticas ocorrem em situações históricas, discursivas e materiais específicas" (Nicolini \& Monteiro, 2017, p. 121). Com base nesse entendimento tratamos das conexões entre práticas ou ações.

Ao analisarem essas conexões em redes de ação Lindberg e Czarniawska (2006) as identificaram como sendo cognitivas, emocionais e miméticas, ocorrendo em articulações nas quais se destacam os objetos de fronteira e os procedimentos de fronteira. Os autores explicam que objetos de fronteira pertencem, simultaneamente, a domínios distintos, com sentidos distintos, mas a estrutura comum permite que eles sejam meios pelos quais as ações se traduzem (transladam), como proposto por Latour (1996), em outra ação.

Por exemplo, Lindberg e Czarniawska (2006) identificaram os pacientes como objetos de fronteira, sobre os quais as ações de assistência à saúde se estabelecem, e as narrativas sobre as ações relacionadas a esses pacientes como sendo processos de fronteiras, pois substituem o contato entre os atores de diferentes domínios no cotidiano das redes de ação. Para os autores, o caráter cognitivo, emocional e mimético das conexões é produzido por meios desses objetos e processos, e, ao mesmo tempo, os produz.

Neste artigo assumimos que essas conexões também são relações de poder, no sentido de um efeito exercido nas relações cotidianas, construído pelas ações nas práticas e fazendo parte delas. Essa construção é uma dinâmica de múltiplas produções sociomateriais, e, neste estudo, ao nos voltarmos 
para o poder como efeito, estamos interessados nas conexões relativas a ele, dentro dessa multiplicidade. O desafio aqui é lidar com essas múltiplas produções sociomateriais em uma investigação. Para lidar com elas propomos articular contribuições de Czarniawska (2004), voltadas para o estudo do que acontece em diversos lugares simultâneos em múltiplas ações conectadas em redes de ação. Tal caminho foi considerado como necessário para abordar as múltiplas produções no cotidiano dos artesãos.

Essa pluralidade que permeia os artesãos envolve uma infinidade de aspectos, pois o artesanato reúne vários fatores como o "desenvolvimento cognitivo, psicológico, político e econômico" (Barbosa \& D'Ávila, 2014, p. 150). No cotidiano esses fatores não se apresentam de maneira simplesmente homogênea e apaziguada, pois as ações levam a relações de poder em trabalhos coletivos, como o artesanato, e remetem ao embate em um jogo entre forças, que ocorre por meio do que Certeau (1998) chama de estratégias e táticas. As estratégias são

ações que, graças ao postulado de um lugar de poder (a propriedade de um próprio), elaboram lugares teóricos (sistemas e discursos totalizantes), capazes de articular um conjunto de lugares físicos onde as forças se distribuem ... Privilegiam, portanto, as relações espaciais (Certeau, 1998, p. 102).

No que diz respeito às táticas, Certeau (1998, pp. 100-101) as conceitua como “a ação calculada que é determinada pela ausência de um próprio. Então nenhuma delimitação de fora lhe fornece a condição de autonomia.... a tática é determinada pela ausência de poder". Essa ausência se refere à impossibilidade do exercício do que está circunscrito em um lugar de poder, como efeito das relações que o produziram. É o poder exercido pelo próprio e com efeitos estratégicos. Nessa ausência o poder enquanto efeito e exercício na ação tática será outro, evidenciado quando Certeau (1998, pp. 116-117) explica que os

procedimentos tecnológicos têm efeitos de poder específicos, obedecem a funcionamentos lógicos próprios e podem produzir uma alteração fundamental nas instituições da ordem e do saber. Resta ainda perguntar o que é que acontece com outros procedimentos ... que não dispõem do elemento preliminar, sempre postulado por aqueles que Foucault elucida, a saber, um lugar próprio no qual possa funcionar a maquinaria panóptica. Essas técnicas, também operatórias, mas inicialmente privadas daquilo que fez a força das outras, são as "táticas".

As táticas não podem contar com os efeitos circunscritos a um próprio, portanto, elas são articuladas pelo outro, aquele que não tem um lugar de poder prescrito, sendo considerado um fraco. Mas ele aguarda um momento de deslize do pan-óptico, e obtém os efeitos da astúcia para articular as táticas em momentos oportunos. Como uma dona de casa em um supermercado, ela decide sua compra baseada em dados que se alteram a todo momento e são heterogêneos, como o que tem em sua dispensa, os gostos dos familiares, os produtos com menor preço naquele momento, as combinações de alimentos, entre outros dados (Certeau, 1998). Dessa maneira, mesmo usando elementos do lugar de poder estabelecido, como pagar pela compra, há espaço criativo para a transgressão, indo além da submissão. Essa é a resistência certeauniana, sútil, golpe a golpe, em momentos oportunos e transitórios.

Por isso, a instabilidade das práticas se destaca nas táticas. De maneira convergente com a abordagem das redes de ação, na abordagem certeauniana as interações entre os atores, decorrentes das ações que ocorrem no tempo e no espaço, produzem atores sociais praticantes de ações, formando conexões. Mas a abordagem não se aprofunda na dinâmica dessas conexões enquanto uma rede interligada de ações, uma contribuição aqui obtida da abordagem das redes de ação. Por outro lado, Certeau (1998) permite enfatizar a dinâmica das relações de poder e resistência nas conexões entre as ações. A abordagem proposta viabiliza um olhar para os lugares de poder estabelecidos e suas transgressões, o que permite identificar relações associadas a esses lugares e transgressões que são produzidas pelas ações e parte delas, bem como de suas conexões em uma rede de ação.

O desafio dessa articulação envolvendo a abordagem certeauniana e a perspectiva das redes de ação de Czarniawska (2004) é conciliar aspectos epistemológicos inconsistentes entre ambos. Uma inconsistência com a qual se deve lidar envolve as diferentes interpretações sobre como a agência se 
manifesta na abordagem certeauniana. Para Smith (2014, p. 10, tradução nossa) é necessário criticar a abordagem pois nela os "agentes que utilizam a tática não atuam em uma autonomia real. Em vez disso, eles são um produto da imposição da estrutura". Discordando desse entendimento, Fadil e Fernando (2015, p. 66) afirmam que a abordagem "reconceitualiza a agência como uma mobilização tática do poder". De maneira convergente com esse último entendimento, Cook (2014) defende que Certeau reconhece a agência ao tratar da resistência. Em comum, as diferentes interpretações, mais ou menos críticas, associam a agência à tática na abordagem certeauniana, mas entendemos que isso é uma simplificação da maneira que o autor trata o tema.

O importante nessa discussão sobre como a agência se manifesta na obra certeauniana é reconhecer que Certeau (1998) apresenta elementos que o afastam de um entendimento tradicional de agência, isso ocorre quanto ele articula tanto as estratégias, quanto as táticas. Como explica Poster (1992), a abordagem certeauniana, assim como a de outros pós-estruturalistas, rejeita a centralidade do sujeito, em uma lógica de agência individual, mas diferentemente de outros autores pós-estruturalistas, ao fazer isso a abordagem certeauniana não rejeita a ideia de resistência. Ou seja, ele rejeita a agência, mas não a resistência. Essa ênfase na resistência pode levar ao equívoco de afirmar que o autor adota a agência individual, pois destaca a resistência em práticas de indivíduos, exemplificadas de maneira detalhada em sua obra. Mas esse equívoco exige desconsiderar peculiaridades da abordagem certeauniana, que a afasta da visão tradicional de agência individual.

Para Certeau (1998) a resistência não ocorre em função dos indivíduos, ela ocorre em virtude das relações táticas, que dependem das relações estratégicas na sociedade nas quais elas se inserem, o foco da análise não está no indivíduo, mas nas relações de poder referentes às ações que têm o sujeito social como "o seu autor ou veículo" (p. 37).

Esse entendimento remete à convergência entre a abordagem certeauniana e a das redes de ação. Como explicam Napolitano e Pratten (2007, p. 5, tradução nossa), entre os precursores que marcam a abordagem pós-estruturalista a obra certeauniana "pode ser lida como antecipando as reflexões atuais sobre a natureza desse paradigma. Ou seja, um repensar da intersubjetividade e da agência de agentes não humanos contra nossa própria distinção antropocêntrica entre objetos 'naturais' e seres 'humanos"'. $\mathrm{Na}$ abordagem certeauniana a "agência não é mais algo que você possui ou não. Em vez disso, é algo que você mantém em relação a um campo social habitado com outros atores sociais. A agência é, portanto, altamente dependente de situações sociais específicas" (Utas, 2005, p. 407, tradução nossa).

Essa concepção é compatível com o entendimento de Czarniawska (2004) sobre a relação entre ação e intenção. Para a autora, a intenção é uma interpretação a posteriori, atribuída a um evento ou movimento quando eles são relacionados com a ordem social em que se inserem, sendo, então, considerados como uma ação. É a interpretação que define essa atribuição a humanos ou não humanos, a intenção não é algo que pertence a eles. Da mesma maneira, quando Certeau (1998) foca as relações e trata da capacidade de transgressão do indivíduo, essa capacidade é uma interpretação a posteriori a partir das relações sociais vigentes, não é uma característica intrínseca ao ser humano.

Em relação à materialidade, além de ela se destacar na obra do autor, não identificamos um impedimento para que as coisas também sejam consideradas um suporte para receber aquela interpretação sobre a atribuição, mencionada por Czarniawska (2004). Entretanto, deve ficar claro que nas análises de Certeau $(1998,1986)$ as coisas se destacam como parte das relações, sem a preocupação de apresentá-las como simétricas em relação aos humanos, como faz Czarniawska (2004). Isso pode ser observado em diversas passagens na obra de Certeau (1986, p. 213), por exemplo, na sua análise do envolvimento entre os computadores e a historiografia, quando afirma que "pelo tributo pago ao computador, a historiografia produz a crença de que não é uma ficção". Outro exemplo surge quando ele apresenta a reprodução de uma aldeia no Shelburne Museum, de Vermont, EUA: "essa aldeia abarrotada de objetos abandonados e recolhidos remetia, por eles aos murmúrios ordenados de cem aldeias passadas ou possíveis, e o visitante se punha a sonhar com esses traços imbricados com mil combinações de existências" (Certeau, 1998, p. 82). 
A despeito dessas e de outras manifestações na obra do autor destacarem a importância dos não humanos nas relações, é necessário reconhecer que ao tratar dessas relações ele acaba por enfatizar o papel das pessoas em veiculá-las, o que também pode remeter à interpretação, aqui rejeitada, de que a abordagem certeauniana se volta para a agência individual. Para rejeitar esse entendimento nos baseamos no fato de que para o autor é

a relação (sempre social) que determina seus termos, e não o inverso, e que cada individualidade é o lugar onde atua uma pluralidade incoerente (e muitas vezes contraditória) de suas determinações relacionais. De outro lado e, sobretudo, a questão tratada se refere a modos de operação ou esquemas de ação e não diretamente ao sujeito que é o seu autor ou veículo (Certeau, 1998, p. 38).

Ou seja, o autor dá destaque ao indivíduo, mas não em virtude de sua intencionalidade ou agência individual, mas como um autor ou veículo. De maneira semelhante, nas redes de ação as ações "são sempre sociais ou coletivas, mesmo quando são realizadas por indivíduos" (Lindberg \& Czarniawska, 2006, p. 293, tradução nossa). Portanto, entendemos que há espaço para articularmos os não humanos, em termos de relações sociais, desde que eles também sejam considerados como autor ou veículo e se reconheça que a questão da simetria, presente na abordagem das redes de ação, não faz parte das preocupações certeaunianas, que também não apresenta uma oposição explícita quanto a isso.

Ao reconhecermos que a preocupação está nas práticas ou ações e não nos indivíduos, e que os não humanos também participam das práticas, eles ganham importância ao considerarmos as relações de poder e resistência produzidas pelas ações e que fazem parte de suas conexões. Tais relações não são comumente exploradas em estudos sobre redes de ação, mas têm o potencial de revelar o que sustenta, em parte, as conexões dessas redes.

$\mathrm{Na}$ abordagem certeauniana, de maneira convergente com a perspetiva de redes de ação, as interações entre atores organizacionais, decorrentes das ações que ocorrem no tempo e no espaço, produzem atores sociais praticantes de ações, e isso constrói conexões entre as ações. Em conjunto, as duas abordagens permitem abordar o organizar do artesanato de uma maneira específica: enquanto resultado de redes de ação interligadas por conexões que incluem relações de poder produzidas pelas ações, manifestadas em estratégia e táticas estabelecidas pelas ações nas tensões cotidianas entre lugares de poder estabelecidos, e de táticas transgressoras, que fazem a bricolagem de elementos desses lugares nas transgressões.

Para confrontar empiricamente o potencial dessa abordagem conjunta e destacar os aspectos que permite desvelar, ela foi aplicada em uma investigação sobre o organizing da atividade artesanal das filezeiras do Pontal da Barra, em Maceió, Alagoas, discutida a seguir.

\section{Percurso Metodológico}

A unidade de análise adotada são as ações cotidianas das filezeiras do bairro do Pontal da Barra, em Maceió/AL. A coleta de dados ocorreu entre junho de 2016 e outubro de 2016, por meio de observação participante, shadowing e entrevistas semiestruturadas.

A observação participante foi adotada com o propósito de assumir o papel de um membro organizacional (Czarniawska, 2004). Houve a participação em doze reuniões da associação das artesãs. Além disso, três vezes na semana, num total de dezesseis semanas, foram realizadas as atividades de vendas, afazeres diversos do estabelecimento, e bordando como uma aprendiz no cotidiano de duas lojas na qual o artesanato era produzido e comercializado e que as proprietárias participavam da associação. As anotações de campo se sucederam às observações e em procedimentos relacionados com a pesquisa e geraram um diário de campo, digitado no software Word. 
Como as relações da presidente da Associação com diferentes atores, instituições e lugares extrapolavam o local onde o filé era vendido ou produzido, ela foi acompanhada por meio do shadowing, que consiste em seguir o praticante ao longo do seu dia a dia (Czarniawska, 2008). Ele foi aplicado num período de seis dias corridos, de segunda a sábado, das 11:00 h às 17:00 h, gerando notas de campo e um diário digitado no software Word.

Quanto às entrevistas semiestruturadas, os critérios de seleção dos sujeitos foram: ser um(a) artesão(ã) do bordado filé e residir no bairro do Pontal da Barra. Foram realizadas 21 entrevistas semiestruturadas com filezeiras do bairro com a utilização de um roteiro de entrevista, todas gravadas e transcritas de forma literal com o uso do software Word. As entrevistadas bordam há mais de dez anos, têm idades bem distribuídas, com duas ou quatro delas situadas em cada faixa de dez anos, entre 20 e 80 anos de idade. Para assegurar a confidencialidade elas foram identificadas pela letra F, seguida de uma numeração, sem associar a esses códigos dados pessoais que permitam identificá-las.

Os dados foram tratados por meio da Análise de Conteúdo, utilizando categorias temáticas, definidas a posteriori, a partir dos dados (Bardin, 1979). A unidade de registro adotada foi o tema. Ele expressa significados específicos surgidos de recortes dos dados brutos, realizados em função do objetivo proposto. Inicialmente foram realizadas várias leituras do material coletado, buscando categorias temáticas que perpassassem os temas relacionados com o objetivo e permitissem organizálos. Os temas que surgiam diretamente relacionados foram integrados em uma mesma categoria. Após esse processo identificamos quatro categorias básicas: (a) o cotidiano bucólico em seu dinamismo regido pela sobrevivência, (b) práticas organizacionais isoladas e vinculadas a uma comunidade artesã, (c) dúvidas e expectativas encontradas na comunidade artesã e (d) a sociomaterialidade operante no artesanato bordado filé do Pontal da Barra.

A codificação nessas categorias ocorreu por meio de recortes de trechos dos dados demarcando temas. Esses trechos foram colados, conforme a categoria, em uma planilha do Software Excel com colunas com os elementos necessários para identificar a origem dos dados e contribuir para a sua análise, facilitando a ordenação dos trechos por temas relacionados e a identificação de conteúdos comuns. A partir desse processo foi possível a interpretação dos dados o que permitiu apresentar a análise a seguir.

\section{A Sociomaterialidade do Filé e os Domínios da Sociedade}

O processo de produção do Bordado filé se inicia com a confecção da rede que ao ser finalizada é denominada de malha. Nesta etapa, a artesã se utiliza dos pés, um molde na espessura da malha que se deseja obter, uma tesoura, a linha e uma fita métrica. Em seguida, ela faz os pontos sobre a rede anteriormente preparada. Atualmente, em ambas as etapas são utilizados fios de algodão, pois a peça de filé em Alagoas é totalmente feita nesse tipo de linha. Estando pronta a malha, a artesã se utiliza de um tear, a agulha de bordar, a linha, uma tesoura e uma fita métrica para preencher o bordado com pontos e cores desejados. Após o bordado, a goma caseira é utilizada em determinados tipos de peças. Depois de secar, a peça é retirada da grade e aparada com a tesoura.

O uso exclusivo do algodão, não apenas na linha, é algo presente em estudos sobre o artesanato, em virtude de suas características funcionais e estéticas que remetem a algo artesanal (Sapiezinskas, 2012), ou demarcando uma tradição regional com finalidade mercadológica (Bento \& Silva, 2016). Mas neste estudo consideramos essas e muitas outras alternativas apenas como parte dos possíveis efeitos do uso ou não do algodão nas redes de ação do artesanato que envolvem outros efeitos em termos de relações de poder.

Ao observar a sociomaterialidade descrita acima e identificar alterações nela nas redes de ação evidenciamos a dinâmica das relações de poder. Em relação ao algodão observamos isso quando o uso da chamada linha de cordão surgiu como uma ação conectada nas redes. 
“aqui no Pontal não podia vender filé de outro lugar ... porque vem filé... do Ceará é diferente ... fazem de cordão, é um filé, assim, eu diria de segunda classe. Aí eu acho que esse filé não poderia ser vendido aqui" (Entrevistada F21).

"não é linha [de algodão]. São fios coloridos, tinturados, são malhas maiores, e vende como se fosse do Pontal da Barra, de baixa qualidade. E aí me dá raiva também daqui do pessoal do Pontal que tem donas de loja que compra! O pessoal de Fortaleza vem com caminhão enorme, cheio!” (Entrevistada F10).

Durante a coleta de dados não foi observado o uso do cordão pelas filezeiras do pontal, entretanto, muitas lojas das filezeiras vendiam produtos feitos de cordão, principalmente saídas de praia e toalhas de mesa, e raramente informavam quando não era de algodão. De maneira heterogênea, o fato de também venderem o produto não impede a insatisfação das filezeiras, como se observou nos fragmentos acima e em muitas outras manifestações. E o fato de não avisarem quando um produto não é de algodão, pervertendo o lugar de poder do artesanato tradicional que é contra o cordão, remete a uma resistência veiculada pelas filezeiras (Certeau, 1998), mas produzida nas interações entre humanos e não humanos.

Aqui temos um exemplo da articulação teórica proposta contornando diferenças entre como pessoas e coisas são tratadas na abordagem certeauniana e na de redes de ação. São manifestações da heterogeneidade nas micropráticas do organizar (Duarte \& Alcadipani, 2016) do artesanato. Um dos efeitos de poder nas redes de ação do artesanato que produz essa conexão heterogênea na sociomaterilidade do filé é a possibilidade de realizar ou não uma venda nas lojas. Esse efeito de poder faz parte tanto da conexão do uso da linha de cordão quando da de algodão. A primeira vende pois é barata, a segunda por ser tradicional. A conexão do uso das duas nas redes de ação envolve uma distribuição de poder na qual ambas se sustentam. Elas fazem parte de ações veiculadas nas relações entre artesãs, ferramentas e matérias-primas, remetendo à sociomaterialidade do bordado. Ao mesmo tempo, o bordado é um objeto de fronteira, pois liga diferentes domínios (Lindberg \& Czarniawska, 2006).

De um desses domínios, o do estado, surge um ator de destaque na rede de ação e diretamente relacionado com a heterogeneidade em relação às linhas de cordão ou algodão (materialização da relação entre o barato e o tradicional), o selo, como chama F12.

“a gente faz aqui com linha, 100\% algodão, e o filé de Fortaleza é cordão, então ele ganha muito... aqui tem pessoas que vende, porque ele sai mais barato, mais em conta e tal, e é um grande concorrente ... Por isso que a preocupação era de ter o selo ... que indicasse o filé” (Entrevistada F12).

Trata-se de um selo de certificação de origem que, segundo Bento e Silva (2016), pode ser uma ferramenta de marketing e estratégia de desenvolvimento local pelo artesanato. Neste estudo consideramos tais possibilidades como parte dos efeitos possíveis de serem alcançados ou não na rede de ação que inclui o selo. Quando a adoção dele se conecta na rede ela altera a distribuição de poder na direção da tradição e, no futuro, os efeitos de poder podem levar à ruptura da conexão com o uso da linha de cordão, e ou conectar outras ações, e ou, como sugerem os autores, promover o desenvolvimento local, entre muitos efeitos possíveis.

$\mathrm{Na}$ rede de ação que produz esses efeitos a instância estadual institucionaliza o que é um patrimônio cultural. De acordo com D’Ovidio e Pradel (2013), essa institucionalização tem por base a existência de um equilíbrio entre a sobrevivência econômica e a liberdade artística. Essa visão otimista é compartilhada por Bento e Silva (2016), ao defenderem o papel do Estado na patrimonilização e seu uso no desenvolvimento local. Em uma visão menos otimista, J. S. Oliveira et al. (2012) discutem o ponto de vista do poder público sobre o artesanato e fica claro certo papel normatizador do que é ou não artesanato e a pressão a que submetem o artesão. Mas, assim como Leistner (2018), as autoras evidenciam certo espaço construído pelo artesão a despeito da pressão de instituições públicas. Esses estudos não abordam a patrimonialização do artesanato, mas ela é um tipo de prescrição do Estado.

Diferentemente desses estudos, neste artigo tratamos essas possíveis implicações da atuação do Estado, manifestadas aqui na patrimonialização, como possíveis efeitos nas redes de ação do bordado a 
partir da conexão de ações como adotar ou não um selo ou seguir ou não diretrizes definidas em prescrições do filé como patrimônio, alterando distribuições de poder.

Isso ocorre pois, como objeto de fronteira, ao pertencer, também, ao domínio do estado, o bordado permitiu a tradução de ações institucionais de atores ligados ao Estado por meio da atividade artesanal. Isso levou a efeitos de poder conectando novas ações nas redes de ação do artesanato, por exemplo, ações relacionadas com o reconhecimento do filé como Patrimônio Cultural Imaterial do estado de Alagoas, como o efeito de poder usar o selo de certificação de Indicação Geográfica (IG), recebido em 2016 (Anorim, 2016).

Ou seja, as redes de ação se traduziram na definição do artesanato do filé como um patrimônio cultural do estado. Ao mesmo tempo, elas produziram como efeito o lugar de poder privilegiado da institucionalização de um patrimônio cultural que, a partir das conexões entre elas, incluía o bordado filé. Como parte dessas conexões estão as relações de poder, foco da presente análise. Tais relações se sustentam na produção daquele lugar de poder por meio de ações que possibilitam as estratégias cotidianas (Certeau, 1998). São ações de diferentes domínios, das artesãs, do estado, dos compradores de artesanato, entre outros, interligados pelo bordado filé, que permite uma tradução comum.

Ainda dentro do domínio do estado, assim como identificado em outros estudos sobre o artesanato (Moraes \& Helal, 2017), ficaram evidentes diversas ações relacionadas com políticas públicas impactando no artesanato. Neste estudo tais ações se conectam nas redes de ação do artesanato e atuam no bairro Pontal da Barra. Ele foi marcado pelo desenvolvimento do turismo, na década de 1970, época da divulgação do bordado filé pela Empresa Alagoana de Turismo (EMATUR), em exposições interestaduais, e após o acesso facilitado, com a construção de uma rodovia paralela ao mar ligando o bairro ao centro da cidade (Sant'Ana, 1989). Antes, entre as ações das artesãs estava o deslocamento para as portas de hotéis, repartições públicas ou ao cais do porto para a venda do bordado filé. Como efeito das ações mencionadas, nos dias atuais, apesar de existirem pontos de venda em outros locais da cidade, a maioria delas permanece no Pontal da Barra, o bairro do filé, que conta com cerca de 120 lojas de bordado filé e mais 25 lojas de produtos artesanais diversificados.

Essa relação entre turismo e artesanato é reconhecida nos mais diversos estudos sobre o tema, seja com uma conotação crítica, das submissões negativas (Marquesan \& Figueiredo, 2014), seja como algo positivo que contribui para o seu desenvolvimento (Bento \& Silva, 2016; Vargas \& Cancelier, 2018). De maneira distinta a esses estudos, neste artigo nos interessa revelar como a dinâmica das ações conectadas nas redes de ação ocorre tendo atores como o turista, os agentes de viagens, os empresários do setor hoteleiro, entre outros envolvidos, veiculando ações conectadas nas redes de ação em torno de relações de poder.

Antes, a comercialização do filé dependia de ações em transgressões de lugares de poder estabelecidos por outras ações, que, muitas vezes, sustentavam a proibição dessa comercialização em locais considerados impróprios, como as repartições públicas. Mas as redes de ação produziram no organizar do artesanato a (re)construção de conexões. Elas geraram relações de forças na qual se demarcou o lugar de poder privilegiado do bordado filé, que incluiu o não humano, o bordado filé, também no lugar do próprio. Atualmente, o bordado faz parte de um bairro e de associações de artesãs ao longo do estado, tem regras formais sobre o que é ou não, um registro oficial como patrimônio, entre outras manifestações que são efeitos, chamados aqui de poder, produzidos pelas ações e que as compõem.

Tais efeitos das ações discutidas até aqui evidenciam a existência de domínios distintos, demarcados em ações de atores internos ao artesanato (artesãs, ferramentas, matéria prima), de políticas públicas e de outras instituições da sociedade traduzidas no artesanato e ligadas por meio dele. Esses domínios fazem parte de redes de ação que se estendem à produção cotidiana do filé, na atividade diária na qual ferramentas, corpos e matérias-primas são conectados em ações para produzir um bordado e revelam conexões com outros domínios. 


\section{A Sociomaterialidade nos Domínios da Produção Cotidiana}

No cotidiano das artesãs as discussões entre elas nas reuniões da associação eram ações que resultavam em desarmonias e ambiguidades. Isso também ocorria em ações relacionadas a não humanos, por exemplo, nas trocas de mensagens no aplicativo WhatsApp, que interagia com a reunião e as discussões. Ele era o meio mais utilizado para a comunicação, como o horário e local das reuniões eram informados no mesmo dia, havia uma dependência desse ator não humano para realizar a reunião.

Outro elemento não humano mencionado são as atas das reuniões. "Nenhuma anotação sobre decisões, acontecimentos ou planejamentos eram registrados em ata, apesar das reiteradas solicitações, por parte dos associados para que isso fosse feito" (diário de campo).

Leistner (2018) também evidencia que alguns artesãos não registram formalmente suas atividades, mas ele associa isso à falta de interesse. Mas neste estudo consideramos isso como uma ação conectada às redes de ação por um efeito de poder. A ata, enquanto elemento institucionalizado do lugar de poder da associação, para registro de decisões, é transgredida em táticas cotidianas no organizar do artesanato, permeado pela informalidade existente nas reuniões da associação das artesãs, sem registro sobre decisões, abrindo espaço para relações de poder conectando ações de oportunismo e de conflito.

Esse organizar é o resultado de ações em processos heterogêneos e distintos, que mesmo não possuindo coerência entre si apresentam alguma identidade em comum (Alcadipani \& Tureta, 2009). Em termos materiais, ao tempo em que uma identidade entre as artesãs associadas era continuamente construída, observou-se a influência da ausência de estrutura física para a associação como parte dessa construção. $\mathrm{O}$ fato da Associação não ter uma sede remetia a ações que a afastavam da identificação por parte da comunidade de que era algo organizado. A sede, existindo ou não, era um não humano que colaborava ou atuava na atividade humana, ao tempo em que se destacava pela presença e movimento espacial, compondo a organização (Wilhoit \& Kisselburgh, 2015).

Além da ausência da sede, por meio da observação participante também se notou o papel de outro não humano nas relações de poder em torno do artesanato, o já mencionado aplicativo de comunicação WhatsApp usado como rede social. Ele também servia para informar a quantidade diária de ônibus de turismo que iriam visitar o bairro. Durante a observação ficou claro que muitas artesãs apenas aguardam a vinda dos clientes, mas outras, a partir de atuação do aplicativo, deslocavam-se no horário das visitas dos grupos, para recebê-los e atraí-los até suas lojas. Leite e Sehnem (2018) também identificam o uso de redes sociais para divulgar produtos do artesão, mas aqui trata-se de literalmente buscar o cliente.

Na sociomaterialidade no organizar do artesanato, para várias artesãs o uso do WhatsApp passou a fazer parte das redes de ação da qual, para todas elas, já faz parte o uso de agulha, linha, rede, tear e tesoura. As ações envolvendo os cinco últimos objetos tradicionais, dentro da sociomaterialidade do organizar do artesanato, produzem relações de poder, ou seja, efeitos, que as conectam e as traduzem no bordado. Ao mesmo tempo, essas ações demarcam o lugar de poder das artesãs; dele, define-se o que elas são, como devem usar os cinco objetos para ser artesã, dentre outras estratégias de produção de bordado e de artesãs. Por sua vez, o bordado, enquanto objeto de fronteira, permite que as ações ultrapassem domínios. É o caso do uso do WhatsApp, no domínio das redes sociais, esse uso é conectado nas redes de ação para vigiar quando o ônibus com turistas chega no bairro.

Enquanto usam os cinco objetos tradicionais, como está institucionalizado no lugar de poder das artesãs, o WhatsApp as provoca com uma tática transgressora (Certeau, 1998), Essa tática se concretiza no aviso oportunista de que uma quantidade atrativa de turistas chegou. O instante da chegada do ônibus é usado pelo WhatsApp, em uma transgressão momentânea que tenta romper, por instantes, com o uso dos outros objetos institucionalizados como próprios do bordado. Várias artesãs param o que estão fazendo para consumir o consumidor do artesanato, até que ele chegue em sua loja. Esse efeito da ação do WhatsApp é uma relação de poder e transgressão heterogênea. 
Outra interferência recente nas redes de ação é o papel do uso da fita métrica. Na observação participante foi identificado o seu uso apenas por artesãs que seguem os padrões para receber a certificação de Indicação Geográfica (IG). Aqui temos o empate entre ações em dois lugares de poder distintos, com o bordado, enquanto objeto de fronteira, conciliando diferenças: o lugar de poder do patrimônio cultural, que passou a incluir o bordado filé; o lugar de poder da artesã de bordado filé. Um lugar não deixou de existir em função do outro, em ambos são articuladas ações em estratégias, muitas vezes convergentes com os dois, como a venda do bordado feito pela artesã para outros estados por ser reconhecido como original pela certificação. Mas também existem estratégias divergentes entre eles. $\mathrm{O}$ uso ou não da fita métrica na produção não afasta a artesã do que é ser uma bordadeira de filé, não afeta o que está institucionalizado como identidade dela, mas o não uso a exclui do rol das que podem ser certificadas, segundo o que está institucionalizado na patrimonialização.

Poderíamos chamar isso de ação de resistência, mas para Certeau (1998) a resistência não conta com um lugar de poder estabelecido. Nesse caso temos um embate entre lugares de poder estabelecidos, que se entrecruzam. Por isso optamos por chamar de conflitos entre ações em lugares de poder privilegiados na sociomaterialidade do artesanato.

Ainda em relação à produção do artesanato, na sociomaterialidade do seu organizar se destacou o uso do tempo e corpo para bordar, quando a rede de ação que produz o artesanato também produz filezeiras, com sentimentos positivos e interferências no corpo e tempo.

"A gente faz a rede, coloca no tear e aí vai fazendo a proporção que você tem vontade de fazer né? Quando eu quero paro, me enrolo, me deito, descanso, quando eu quero costuro" (Entrevistada F21).

"o compromisso que eu quero é com, com o meu filé, eu não quero pegar compromisso dos outros, de repente uma pessoa me pega assim, "eu quero cinquenta peças pra daqui a sessenta dias". Eu não vou dar conta! Pra minha estrutura óssea, não dá, né?" (Entrevistada F17).

Durante as observações ficou clara a ação de demarcação de um tempo próprio para o bordado, mas ações levando a grandes volumes de trabalho alteravam esse tempo e produziam sofrimento no corpo, impondo obrigações que vinculavam as artesãs a uma funcionalidade (Sennett, 2009). Como destacam Marquesan e Figueiredo (2014), ao perverter a lógica das artesãs isso as pressiona. Além disso, a ação de alterar esse tempo envolve efeitos no corpo.

Figueiredo e Ipiranga (2015) destacam que o artesão, assim como outros profissionais, corporifica a sua maestria. Neste estudo identificamos que essa corporificação envolve efeitos de poder que conectam a ação da dor pela maestria nas redes de ação do artesanato. A dor é parte do artesanato no corpo e do corpo no artesanato. Isso ficou claro na observação participante, durante a experiência da prática do bordado filé, e, em duas horas, foram bordados dois pequenos marca-textos. As dores no corpo prolongaram-se pelo dia seguinte.

Não se trata da dor da maestria, pois era o corpo de uma aprendiza de artesã, vivenciando a ambiguidade do prazer e da dor de bordar. A dor da maestria foi observada quando "artesãs experientes sentiam dores ao bordar" (diário de campo) e delas surgiu o efeito das dores valorizarem o bordado, na ação de narrá-las aos turistas.

"Eu digo assim, ora, moça, ou... ou... ou homem, etc., chega aqui. ... você acha caro? Olhe direitinho como é que faz. Aí começo a trabalhar. Olha, tá vendo como é que é? Ponto por ponto à mão isso aqui, é trabalho que a gente fica com a coluna, quase... eu estou aqui, os pés queimam que só pimenta quando eu... quando me sento. Meus pés queima. A... a... os braços doem, a vista dói ..." (Entrevistada F13).

A ação de expressar a dor para valorizar o bordado ao turista não era algo institucionalizado, ela ocorria em oportunidades específicas. São microimprovisações possíveis pela experiência que revela o potencial das ações (Cunha, Miner, \& Antonacopoulou, 2017). Elas são táticas, capazes de resistir ao lugar de poder produzido pelas ações que demarcam a identidade do que é ser uma artesã do bordado filé e que produzem o artesanato como algo positivo. Há uma resistência a esse lugar na ação de valorizar o bordado em virtude de aspectos negativos envolvendo sua produção, remetendo à heterogeneidade $\mathrm{e}$ 
instabilidade, pois não é algo constante. Por outro lado, também surgiu o artesanato como algo positivo, que supera a dor, evidente na ação de narrar o prazer de fazer o artesanato.

"Aí mas é assim, o filé pra mim, filha, além de ser uma terapia, é um prazer, sabe? Eu sinto muita dor na coluna, eu tenho quatro hérnias de disco ... Aí o fisioterapeuta que eu tava fazendo: "Ah! Dona ..., se a senhora não deixar de fazer o filé, a senhora não vai ficar boa!". Eu disse: "então eu vou continuar doente, mas eu vou fazer o meu filé!". É porque se eu melhoro do braço eu vou cansar a mente, já pensou o dia todinho eu parada fia, dento de casa, né pior não?" (Entrevistada F17).

Aqui se identificam ações em um empate entre dois lugares de poder: um no domínio da medicina/fisioterapia, produzido por ações que definem prescrições para todos terem saúde; e outro no domínio das artesãs, produzido por ações que definem a artesã do filé. Há convergências, por exemplo, na ação de diminuir o ritmo de trabalho, conectada nas redes de ação pelo efeito de poder da proteção do corpo. Assim como há divergências, quando a ação da prescrição médica ou fisioterápica é conectada às ações de ignorar essa prescrição e dar continuidade à produção do artesanato. As três usando o bordado como objeto de fronteira.

Pena, Freitas e Cardim (2011) revelaram consequências negativas do trabalho artesanal para a saúde em virtude do ritmo e do esforço repetitivo, entre outros aspectos, e propõem a busca por alternativas técnicas e ergonômicas mais saudáveis. Neste artigo essa busca e outras ações relacionadas com a saúde revelam como os efeitos de poder conectam ações relativas a esse domínio, ampliando as redes de ação que compõem o organizar da produção do filé.

Outro domínio destacado é o de compradores de artesanato, com atores externos ao bairro, ao estado e ao país. No organizar do artesanato, a rede de ação nesse domínio tem como efeito a produção da compra, do cliente, do turista, do objeto cultural, do souvenir da viagem, dentre outros atores. Na conexão com outras redes de ação, ela propicia o que outros autores vão identificar como a ressignificação do artesanato e da identidade do artesão (Figueiredo \& Marquesan, 2014; Leistner, 2018). Aqui tratamos essa ressignificação como um efeito conectando ações que produzem o lugar de poder da lógica econômica do mercado, na qual as ações definem o preço e o valor de tudo no mercado, inclusive de souvenirs ou de um artesanato original. Essas ações entram em tensão com as ações da rede produtora do lugar de poder da artesã, com base nas quais o filé é mais do que uma oferta comum no mercado. Novamente há o embate entre ações em lugares de poder distintos.

Temos a resistência com a possibilidade de transgredir ambos os lugares de poder, por meio de ações de consumo criativas veiculadas por atores fracos, mas que contam com a astúcia para bricolar elementos dos lugares de poder (Certeau, 1998). Isso ocorre nas ações de comprar um souvenir ou o artesanato único das filezeiras, ambos na forma da aquisição do mesmo bordado, que tem significados heterogêneos (souvenir ou artesanato único), cada ação inserida em um dos dois lugares de poder. Entretanto, em um instante, surge outra ação, oportunista, transgressora relacionando atores sociais diversos, como turistas, celulares, filezeiras, ferramentas, aproveitando o momento em que o bordado está sendo produzido: são registradas fotos das filezeiras produzindo, com os turistas durante o processo e deles com as ferramentas. É produzida uma história e ela passou a ser consumida, no lugar das previsíveis compras de um souvenir ou de um artesanato único das filezeiras.

Esse último domínio, dos compradores de artesanato, evidenciou novamente a heterogeneidade do bordado, mas ela se manifestou em outros atores aqui tratados e pode ocorrer com qualquer outro, dentro da sociomaterilidade do organizar do artesanato.

Entre domínios distintos, interligados pelo bordado como objeto de fronteira (Lindberg \& Czarniawska, 2006), os efeitos de poder que conectam as ações e redes nas redes de ação produzem e sustentam a dinâmica dessa heterogeneidade. A partir das redes de ação foi possível compreender a articulação de múltiplos lugares simultâneos (Czarniawska, 2004), e deles as ações estratégicas podem ser estabelecidas, levando a convergências e embates entre elas. Em torno de tudo isso, como nos mostra Certeau (1998) e evidenciamos neste estudo, há a resistência transgredindo esses lugares e suas ações. O organizar do filé é produzido por essas mais ou menos instáveis relações de forças, que marcam a produção artesanal. 


\section{Considerações Finais}

Evidenciamos que, em parte, isso ocorre pois existem diferentes domínios, entre os quais identificamos: o das artesãs; o do estado; o das redes sociais; o da medicina/fisioterapia; o dos compradores de artesanato. A articulação entre eles é possível por causa do artesanato como objeto de fronteira, que no organizar em questão é o próprio produto da atividade, o bordado filé. Além disso, nesses domínios existem lugares de poder produzidos pelas ações em estratégias que os sustentam e se sustentam nesses lugares. Essas ações estabelecem relações de poder, que são efeitos das próprias ações e fazem parte das conexões entre elas. Mesmo com essas tensões elas compõem redes, que são, por isso mesmo, heterogêneas.

Além dessas relações de forças baseadas no confronto entre lugares de poder distintos, evidenciamos aquelas produzidas por ações de resistência a esses lugares, no sentido certeauniano do termo, e aos efeitos das ações relacionadas com eles. Essas ações de resistência se conectam de maneira transitória nas redes por meio de efeitos que não respeitam domínios ou lugares de poder e convivem com as outras ações nos momentos em que surgem.

Ao reconhecer essa dinâmica este estudo contribui para a compreensão da heterogeneidade das redes de ação de maneira geral e das que compõem o organizar do artesanato de maneira específica. Do confronto com estudos anteriores sobre artesanato identificamos convergências em termos de aspectos do artesanato do filé já tratados em outros estudos, tais como, o uso do algodão (Bento \& Silva, 2016; Sapiezinskas, 2012), as relações do poder público com o artesanato (J. S. Oliveira, Cavedon, \& Figueiredo, 2012; Leistner; 2018; Moraes \& Helal, 2017), o papel do turismo (Marquesan \& Figueiredo, 2014; Vargas \& Cancelier, 2018), o uso das redes sociais (Leite \& Sehnem, 2018), a corporificação da maestria (Figueiredo \& Ipiranga, 2015) e a saúde das artesãs (Pena, Freitas, \& Cardim, 2011).

Deve ficar claro que mesmo quando abordam o mesmo aspecto os estudos o fazem de maneiras distintas em relação ao poder, foco deste estudo. Por exemplo, Vargas e Cancelier (2018) ao mencionarem o turismo se silenciam sobre o poder e o tratam como algo que desenvolve o artesanato. Já Marquesan e Figueiredo (2014) colocam o turismo como parte da matriz do poder capitalista que causa a perda da liberdade do artesão a favor do mercado.

Dentre os estudos analisados não se identificou nenhum voltado para o poder como um efeito que produz conexões nas redes de ação do artesanato, lacuna preenchida por este estudo como contribuição para o campo. Além disso, quando evidenciamos as ações e efeitos que produzem os domínios e lugares de poder, também revelamos relações de forças nas quais o artesanato não é simplesmente submisso aos lugares de poder, nem fica apenas como espaço de resistência. $\mathrm{O}$ artesanato do bordado filé também conta com um lugar de poder próprio e as ações e efeitos que o produzem entram em tensão com as outras, em conexões das quais essas relações de poder fazem parte. Isso revela o caráter heterogêneo das redes de ação no organizar do artesanato, que também se relaciona com a resistência nas redes de ação.

Um exemplo dessas resistências foi a ação de informar sobre a chegada dos ônibus, que se utiliza do WhatsApp, transgredindo, em parte e de maneira heterogênea entre os atores, o uso dos outros objetos institucionalizados como próprios do bordado, posicionados no lugar de poder produzido pelas ações que definem o que é ser uma artesã do bordado filé. Ou seja, assim como os humanos, os não humanos também veiculam transgressões, uma concepção não explorada claramente nas contribuições certeaunianas, mas evidenciadas neste artigo.

Ao articularmos a abordagem certeauniana com a de redes de ação buscamos conciliar o potencial da discussão sobre as relações de forças em um cotidiano de lugares de poder e transgressões heterogêneas, como a possibilidade de tratar de múltiplos lugares com produções sociais heterogêneas, algo que para nós é típico da complexidade do artesanato. Isso exigiu reconhecer as inconsistências epistemológicas entre a abordagem de Certeau (1998) e a de Redes de Ação (Czarniawska, 2004) e as 
contornar com uma articulação teórica em torno dos entendimentos do poder como efeito e de que indivíduos e demais atores veiculam as ações em redes de ação, conectadas por aqueles efeitos.

Essa articulação permitiu revelar tensões entre ações produtoras de diferentes lugares de poder e as que os transgridem e tratar ambas como efeitos que fazem parte das conexões entre essas ações na rede, efeitos que chamamos de relações de poder no organizar do artesanato. Essa constatação contribui para a compreensão do organizar do artesanato e, também, remete a uma contribuição para o campo de estudo de redes de ação: o reconhecimento de que assim como os aspectos cognitivos, emocionais e miméticos identificados por Lindberg e Czarniawska (2006) conectam ações nas redes de ação, essas ações também são conectadas por relações de poder que são efeitos das ações.

Por fim, cabe destacar que essa contribuição para o organizar do artesanato permite abordar, em estudos futuros, um aspecto não identificado nos estudos organizacionais baseados em redes de ação analisados, e que foge do escopo deste estudo: as conexões a partir das relações de poder produzidas por não ações. Ou seja, por ações que não foram realizadas, tais como a não definição da sede da associação das artesãs do bairro e o não preenchimento das atas. Essas ações produzem relações de poder constitutivas de parte das conexões justamente por não terem sido realizadas, mas existir uma expectativa de que sejam.

\section{Referências}

Alcadipani, R., \& Tureta, C. (2009). Teoria ator-rede e análise organizacional: Contribuições e possibilidades de pesquisa no Brasil. Organizações \& Sociedade, 16(51), 647-664. http://doi.org/10.1590/S1984-92302009000400003

Amorim, M. (2016, agosto 3). Filé produzido na região lagunar é certificado pelo INPI. Fundação Municipal de Ação Cultural, Maceió, AL. Recuperado em 3 de dezembro, 2018 de http://www.maceio.al.gov.br/2016/08/file-produzido-na-regiao-lagunar-e-certificado-pelo-inpi/

Barbosa V. L., \& D'Ávila, M. I. (2014) Mulheres e artesanato: Um 'ofício feminino' no povoado do Bichinho/Prados-MG. Revista Ártemis, 17(1), 141-152. http://doi.org/10.15668/18078214/artemis.v17n1p141-152

Bardin, L. (1979). Análise de conteúdo. Lisboa: Edições 70.

Bento, K. D., \& Silva, I. F. de O. (2016). Selo de autenticidade do artesanato do estado do Ceará: A fusão entre uma ferramenta de marketing e uma estratégia de desenvolvimento local. Revista Brasileira de Gestão e Desenvolvimento Regional, 12(4), 260-283.

Calíope, T. S., Conceição, I. E. P., Santos, S. M. D., \& Pessoa, M. N. M. (2016). A institucionalização da Feira de Artesanato da Beira Mar em Fortaleza, Ceará. Gestão \& Regionalidade, 32(94), 5267. http://doi.org/10.13037/gr.vol32n94.2526

Callon, M. (1986). Some elements of a sociology of translation: Domestication of the scallops and the fishermen of St Brieuc Bay. In J. Law (Ed.), Power, action and belief: A new sociology of knowledge? (pp.196-223). London: Routledge.

Cardoso, B., \& Hirata, D. (2017). Dispositivos de inscrição e redes de ordenamento público: Uma aproximação entre a Teoria do Ator-Rede (ANT) e Foucault. Sociologia \& Antropologia, 7(1), 77-103. http://doi.org/10.1590/2238-38752017v714

Certeau, M. de (1986). Hetero: Discourse on the other. Minneapolis: University of Minnesota Press.

Certeau, M. de (1998). A invenção do cotidiano: 1. Artes de fazer (3a. ed). Petrópolis: Vozes. 
Certeau, M. de (2012). A cultura no plural (7a ed.). Campinas: Papirus.

Corvellec, H., \& Czarniawska, B. (2015). Waste prevention action nets. In K. M. Ekström (Ed.), Waste management and sustainable consumption: Reflections on consumer waste (pp. 88-101). New York, NY: Routledge.

Cunha, M. P., Miner, A. S., \& Antonacopoulou, E. (2017). Improvisation processes in organizations In A. Langley \& H. Tsoukas (Eds.), The SAGE handbook of process organization studies (pp. 559573). London: Sage.

Czarniawska, B. (2004). On time, space, and action nets. Organization, 11(6), 773-791. https://doi.org/10.1177/1350508404047251

Czarniawska, B. (2008). Organizing: How to study it and how to write about it. Qualitative Research in Organizations and Management: An International Journal, 3(1), 4-20. https://doi.org/10.1108/17465640810870364

Czarniawska, B. (2010). Going back to go forward: On studying organizing in action nets. In T. Hernes \& S. Maitlis (Eds.), Process, sensemaking and organizing (pp. 140-160). Oxford: Oxford University Press.

Cook, D. (2014). Art, agency and eco-politics: Rethinking urban subjects and environment $(s)(\mathrm{PhD}$ thesis). Royal College of Art., London, London, UK.

D'Ovidio, M., \& Pradel, M. (2013). Social innovation and institutionalisation in the cognitive-cultural economy: Two contrasting experiences from Southern Europe. Cities, 33, 69-76. https://doi.org/10.1016/j.cities.2012.07.002

Duarte, M. de F., \& Alcadipani, R. (2016). Contribuições do organizar (organizing) para os estudos organizacionais. Organizações \& Sociedade, 23(76), 57-72. http://doi.org/10.1590/19849230763

Fadil, N., \& Fernando, M. (2015). Rediscovering the "everyday" Muslim: Notes on an anthropological divide. Journal of Ethnographic Theory, 5(2), 59-88. http://doi.org/10.14318/hau5.2.005

Faria, A. M., \& Silva, A. R. L. da (2017b). Artesanato nos estudos organizacionais: A literatura brasileira de 2006 a 2015. Revista Pensamento Contemporâneo em Administração, 11(2), 120-135. https://doi.org/10.12712/rpca.v11i2.880

Faria, A. M., \& Silva, A. R. L. da (2017a). Estudos organizacionais baseados em Michel de Certeau: A produção internacional entre 2006 e 2015. Alcance, 24(2), 209-226. http://doi.org/10.14210/alcance.v24n2.p209-226

Feldman, M. S. (2017). Making process visible: Alternatives to boxes and arrows. In A. Langley \& H. Tsoukas (Eds.), The SAGE handbook of process organization studies (pp. 625-635). London: Sage.

Ferreira, T. B., Helal, D. H., \& Paiva, K. C. M. de (2016). Artesanato, aprendizagem social e comunidade de prática: Um estudo com rendeiras em Alcaçuz (RN). Revista Brasileira de Gestão e Desenvolvimento Regional, 12(1), 33-61.

Figueiredo, M. D. (2014). O artesanato enquanto prática e materialidade: argumento para pensar a dimensão estética e os artefatos nos estudos organizacionais. Revista Interdisciplinar de Gestão Social, 3(1), 189-205. http://doi.org/10.9771/23172428rigs.v3i1.8509

Figueiredo, M. D., \& Ipiranga, A. S. R. (2015). How can we define mastery? Reflections on learning, embodiment and professional identity. Brazilian Administration Review, 12(4), 348-364. 
Retrieved from http://www.scielo.br/pdf/bar/v12n4/1807-7692-bar-12-04-00348.pdf. http://doi.org/10.1590/1807-7692bar2015150019

Figueiredo, M. D., \& Marquesan, F. F. (2014). Artesanato, arte, design... Por que isso importa aos estudos organizacionais? Revista Interdisciplinar de Gestão Social, 3(3), 127-143. http://doi.org/10.9771/23172428rigs.v3i3.8508

Figueiredo, M. D., Melo, A. N., Matos, F. R. N., \& Machado, D. Q. (2015). Empreendedorismo feminino no artesanato: Uma análise crítica do caso das rendeiras dos Morros da Mariana, Piauí. Revista Eletrônica de Ciência Administrativa, 14(2), 110-123. https://doi.org/10.21529/RECADM.2015010

Foucault, M. (1977). Vigiar e punir: Nascimento da prisão. Petrópolis: Vozes.

Latour, B. (1996). On actor-network theory: A few clarifications. Soziale Welt, 47(4), 369-381.

Law, J. (1992). Notes on the theory of the actor network: Ordering, strategy and heterogeneity. Systemic Practice and Action Research, 5(4), 379-393. https://doi.org/10.1007/BF01059830

Leite, A. A. V., \& Sehnem, S. (2018). Proposição de um modelo de gestão sustentável e competitivo para o artesanato. Cadernos EBAPE.BR, 16(2), 264-285. http://doi.org/10.1590/1679-395164057

Leistner, R. M. (2018). Entre o tradicional e o moderno: O artesanato de brinquedos de Miriti como "cultura de transição". Revista Brasileira de Gestão e Desenvolvimento Regional, 14(4), 111-133.

Lemos, M. (2017). Collaborative agency in educational management: Constructing a joint object for school and community transformation. Revista de Administração de Empresas, 57(6), 555-566. http://doi.org/10.1590/S0034-759020170604

Lindberg, K., \& Czarniawska, B. (2006). Knotting the action net, or organizing between organizations. Scandinavian Journal of Management, 22(4), 292-306. https://doi.org/10.1016/j.scaman.2006.09.001

Lindberg, K., \& Walter, L. (2013). Objects-in-use and organizing in action nets a case of an infusion pump. Journal of Management Inquiry, 22(2), 212-227. https://doi.org/10.1177/1056492612455242

Marquesan, F. F. S., \& Figueiredo, M. D. (2014). De artesão a empreendedor: A ressignificação do trabalho artesanal como estratégia para a reprodução de relações desiguais de poder. Revista de Administração Mackenzie, $\quad$ 15(6), 76-97. http://doi.org/10.1590/167869712014/administracao.v15n6p76-97

Moraes, J., Sobrinho, \& Helal, D. H. (2017). A implementação de políticas públicas voltadas a atividades artesanais: Análise do Programa de Artesanato da Paraíba. Organizações \& Sociedade, 24(80), 115-134. http://doi.org/10.1590/1984-9230806

Napolitano, V., \& Pratten, D. (2007). Michel de Certeau: Ethnography and the challenge of plurality. Social Anthropology, 15(1), 1-12. https://doi.org/10.1111/j.1469-8676.2007.00005.x

Nicolini, D., \& Monteiro, P. (2017). The practice approach: For a praxeology of organisational and management studies. In A. Langley \& H. Tsoukas (Eds), The Sage handbook of process organization studies (pp. 110-126). London: Sage.

Oliveira, C. F., \& Veiga, A. R., Neto (2008). A negociação do artesanato nordestino nos mercados internacionais. Revista Alcance, 15(3), 291-305. http://doi.org/10.14210/alcance.v15n3.p291-305 
Oliveira, J. S. de, Cavedon, N. R., \& Figueiredo, M. D. de (2012). O artesanato na ótica de quem o produz: Com a palavra artesãos do brique da redenção em Porto Alegre. Revista Interdisciplinar de Gestão Social,1(3), 141-162. http://doi.org/10.9771/23172428rigs.v1i3.10056

Orlikowski, W. J. (2007). Sociomaterial practices: Exploring technology at work. Organization Studies, 28(9), 1435-1448. https://doi.org/10.1177/0170840607081138

Pena, P. G. L., Freitas, M. C. S., \& Cardim, A. (2011). Trabalho artesanal, cadências infernais e lesões por esforços repetitivos: estudo de caso em uma comunidade de mariscadeiras na Ilha de Maré, Bahia. Ciências \& Saúde Coletiva, 16(8), 3383-3392. http://doi.org/10.1590/S141381232011000900005

Popelka, C. A., \& Littrell, M. A. (1991). Influence of tourism on handcraft evolution. Annals of tourism research, 18(3), 392-413. https://doi.org/10.1016/0160-7383(91)90048-G

Poster, M. (1992). The question of agency: Michel de Certeau and the history of consumerism. Diacritics, 22(2), 94-107. https://doi.org/10.2307/465283

Pozzebon, M., Diniz, E., Mitev, N., Vaujany, F., Cunha, M. P., \& Leca, B. (2017). Joining the sociomaterial debate. Revista de Administração de Empresas, 57(6), 536-541. http://doi.org/10.1590/s0034-759020170602

Ramos, S. P. (2013). Políticas e processos produtivos do artesanato brasileiro como atrativo de um turismo cultural. Revista Rosa dos Ventos, 5(1), 44-59.

Sapiezinskas A. (2012). Como se constrói um artesão: Negociações de significado e uma "cara nova" para as "coisas da vovó". Horizontes Antropológicos, 18(38), 133-158. http://doi.org/10.1590/S0104-71832012000200006

Scarbrough, H., Panourgias, N. S., \& Nandhakumar, J. (2015). Developing a relational view of the organizing role of objects: A study of the innovation process in computer games. Organization studies, 36(2), 197-220. https://doi.org/10.1177/0170840614557213

Sennett, R. (2009). O artífice (2a ed.) Rio de Janeiro: Record.

Sant'Ana, M. M. (1989). O Pontal da Barra através de um parecer. Revista do Instituto Histórico e Geográfico de Alagoas, 41, 123-139.

Smith, S. E. (2014). Colonial contacts and individual burials: Structure, agency, and identity in 19th century Wisconsin (Thesis). University of Wisconsin-Milwaukee, Wisconsin, Milwaukee, USA.

Utas, M. (2005). Victimcy, girlfriending, soldiering: Tactic agency in a young woman's social navigation of the liberian war zone. Anthropological Quarterly, 78(2), 403-430. https://doi.org/10.1353/anq.2005.0032

Vargas, D. L. de, \& Cancelier, J. W. (2018). Artesanato e mercado simbólico dos produtos gauchescos: o caso da Vila Progresso em Caçapava do Sul/RS. Revista Brasileira de Gestão e Desenvolvimento Regional, 14(2), 228-246.

Weick, K. E. (1969). The social psychology of organizing. New York: McGrawHill.

Wilhoit, E. D., \& Kisselburgh, L. G. (2015). Collective action without organization: The material constitution of bike commuters as collective. Organization Studies, 5(36), 573-592. https://doi.org/10.1177/0170840614556916 


\section{Autores}

Christianne Lobato Ramalho da Silva

Av. Lourival Melo Mota, S/N, Tabuleiro do Martins, 57072-900, Maceió, AL, Brasil

E-mail: chris.lobato.ramalho@gmail.com; achristianne@ hotmail.com

Alfredo Rodrigues Leite da Silva

Av. Fernando Ferrari, 514, Goiabeiras, 29075-910, Vitória, ES, Brasil

E-mail: alfredoufes@gmail.com

\section{Contribuições}

$1^{\circ}$ autor: Definição do problema de pesquisa, desenvolvimento inicial e aprofundamento da fundamentação teórica, definição de procedimentos metodológicos, coleta de dados, tratamento, análise e interpretação dos dados, redação inicial do texto, revisão final.

$2^{\circ}$ autor: Definição do problema de pesquisa, aprofundamento da fundamentação teórica, definição de procedimentos metodológicos, interpretação dos dados, redação final do texto, revisão final.

\section{Financiamento}

Os autores informam que não houve financiamento para a produção desta pesquisa.

\section{Conflito de Interesses}

Os autores informam não haver conflito de interesses.

\section{Verificação de Plágio}

A RAC mantém a prática de submeter todos os documentos aprovados para publicação à verificação de plágio, mediante o emprego de ferramentas específicas, e.g.: iThenticate.

\section{Material Suplementar}

Os autores optaram por não compartilhar a sua base de dados, e afirmam que o fazem tendo em vista que os dados qualitativos que envolvem anotações e entrevistas foram articulados com muitas informações capazes de revelar as identidades dos respondentes e informantes. Para preservar o sigilo dessas identidades seria necessário omitir boa parte dos dados utilizados. Isso faria com que esses dados compartilhados fossem semelhantes aos que já estão no artigo e não refletissem efetivamente os dados utilizados, não havendo sentido em compartilhar nesse caso. 